\section{Vigor test of (strong) normal intact Amburana cearensis (Allemão) A.C. Smith seedlings}

\author{
Josenilda Aprígio Dantas de Medeiros $^{1}$ (D) Sarah Patrícia Lima Nunes ${ }^{1}$ (D),

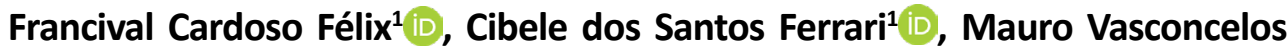 \\ Pacheco $^{1}$ iD, Salvador Barros Torres ${ }^{2 *}$ (iD
}

\begin{abstract}
The aim of this study was to adapt the vigor test methodology of (strong) normal intact seedlings of Amburana cearensis and evaluate efficiency in physiological classification of seed lots. The study was conducted in two stages: morphological characterization of seedlings and physiological analysis of seed lots. To do so, the following tests were carried out: (strong) normal seedlings, germination, emergence, first count, germination speed index, tetrazolium, length of strong normal seedlings, length and dry mass of seedlings. The experimental design was completely randomized. The Tukey and Kruskal-Wallis tests were used to compare the results, and the correlation between the variables was analyzed by Spearman and Pearson coefficients. The seedlings of $A$. cearensis are semi-hypogeal phanerocotylar, with development of normal seedlings on the ninth day after sowing. The vigor test of strong normal seedlings, length of strong normal seedlings, dry matter, and tetrazolium led to physiological classification into different vigor levels. The vigor test of (strong) normal seedlings, the length of strong normal seedlings, and tetrazolium (vigor) were effective for vigor classification of $A$. cearensis seeds.
\end{abstract}

Index terms: Fabaceae, seed quality, forest seed.

Teste de vigor de plântulas normais intactas (fortes) de Amburana cearensis (Allemão) A.C. Smith

RESUMO: Objetivou-se adequar a metodologia do teste de vigor de plântulas normais intactas (fortes) de Amburana cearensis e avaliar a eficiência na classificação fisiológica de lotes de sementes desta espécie. $O$ estudo foi conduzido em duas etapas: caracterização morfológica de plântulas e análise fisiológica dos lotes de sementes. Para isso, realizaram-se os testes de vigor de plântulas normais fortes, germinação, emergência, primeira contagem, índice de velocidade de germinação, tetrazólio, comprimento de plântulas normais fortes, comprimento e massa seca de plântulas. $O$ delineamento experimental utilizado foi o inteiramente casualizado. Para comparação dos resultados foram realizados os testes de Tukey e Kruskal-Wallis, sendo a correlação entre as variáveis analisadas pelos coeficientes de Spearman e Pearson. As plântulas de A. cearensis são do tipo semi-hipógea fanerocotiledonar, com presença de plântulas normais ao nono dia após a semeadura. O teste de vigor de plântulas normais fortes, comprimento de plântulas normais fortes, massa seca e tetrazólio proporcionaram classificação fisiológica em diferentes níveis de vigor. $O$ teste de vigor de plântulas normais fortes, o comprimento de plântulas normais fortes e o teste de tetrazólio (vigor) são eficientes para a classificação do vigor de sementes de $A$. cearensis.

Termos para indexação: Fabaceae, qualidade de sementes, sementes florestais.
Journal of Seed Science, v.42, e202042011, 2020

http://dx.doi.org/10.1590/2317$1545 v 42221611$
${ }^{*}$ Corresponding author
E-mail: sbtorres@ufersa.edu.br

Received: 3/22/2019. Accepted: $11 / 5 / 2019$.

\footnotetext{
${ }^{1}$ Unidade Acadêmica Especializada em Ciências Agrárias, Universidade

Federal do Rio Grande do Norte, Caixa Postal 07, 59280-000 Macaíba, RN, Brasil.
}

2Departamento de Ciências Agronômicas e Florestais, Universidade Federal Rural do Semi-Árido, 59625900 - Mossoró, RN, Brasil. 


\section{INTRODUCTION}

A plant native to the Caatinga (xeric shrubland) ecosystem, Amburana cearensis (Fabaceae) is known as cumaru or amburana-de-cheiro (Almeida et al., 2017). The diverse marketable products obtained from this species come from predatory extractivism (Campos et al., 2013). A. cearensis has been used for food purposes and in creation of soaps and perfumes, but it is also the object of pharmacological studies, which have confirmed the effectiveness of bark extracts as antiseptics against bacteria (Sá et al., 2014) and for anti-inflammatory activity (Lopes et al., 2013).

Morphological characteristics of seedlings can provide important information on the quality of seed lots, since the seedling represents the initial phase of embryo development (Souza et al., 2018). Seedling vigor tests are promising for evaluating the physiological quality of seed lots, for they are able to predict the development and establishment of seedlings in the field.

Normal seedlings are those that have all their essential structures (root system and shoots) with potential for continuing their development and giving rise to normal plants. Normal seedlings can be classified as intact seedlings, seedlings with small defects, and seedlings with secondary infection. Intact normal seedlings can be defined as those that have developed, complete, and healthy essential structures (Brasil, 2013), and as such can also be considered "strong normal seedlings", whereas seedlings with small defects and/or secondary infection can be classified as "weak normal seedlings" (Krzyzanowski and Nakagawa, 1999). Thus, these authors also affirm that seed lots that have a higher percentage of intact normal seedlings have greater chances of emerging and producing normal plants under adverse field conditions.

Characterization of seedlings presented in the Rules for Seed Testing is generalized (Brasil, 2009), since there is no definition of parameters for specific description of the morphology of strong (intact) normal seedlings, weak normal seedlings (with small defects, with secondary infection), and abnormal morphology for native forest species. Therefore, parameters that describe seedling morphology in a detailed manner are necessary with the aim of increasing the effectiveness of the seedling vigor classification test for forest species.

Seedling classification as an evaluative indicator of vigor is a parameter in which seed lots resistant to adversities in the field are detected. It is also an even more specific criterion that is in accordance with the morphological characterization of each species, making vigor classification even more reliable and rigorous (Oliveira et al., 2009). Thus, the aim of this study was to adapt the methodology of the seedling vigor test of Amburana cearensis and evaluate its effectiveness in physiological classification of seed lots.

\section{MATERIAL AND METHODS}

The study was developed with lots of $A$. cearensis seeds coming from the municipalities of Soledade, PB $\left(7^{\circ} 3^{\prime} 25^{\prime \prime} \mathrm{S}\right.$ and $36^{\circ} 21^{\prime} 46^{\prime \prime}$ W; altitude: $521 \mathrm{~m}$ ) and Petrolina, PE (9 $23^{\prime} 34^{\prime \prime} \mathrm{S}$ and $40^{\circ} 30^{\prime} 8^{\prime \prime}$ W; altitude $\left.376 \mathrm{~m}\right)$. In the first stage of experiment, morphological study of the seedlings was performed, analyzing the structures with the aid of a magnifying glass and Munsell Color Chart (Munsell Color, 1963) for determination of color. The seeds were disinfested in $2.5 \%$ sodium hypochlorite for two minutes (Brasil, 2013) and treated with the fungicide Dithane NT (4 g. $\mathrm{kg}^{-1}$ of seed). After that, a hundred seeds were sown in sheets of paper towel (Germitest ${ }^{\circ}$ ), organized in rolls, and placed in a Biochemical Oxygen Demand (B.O.D.) germination chamber at $25^{\circ} \mathrm{C}$ with a 12 -h photoperiod.

Morphological description of the seed germination process proceeded through daily observation and recording of images, from primary root emergence to formation of the first leaves. Formation of a normal seedling was the criterion of germination. Morphological classification of the seedlings was made in accordance with Miquel (1987), considering the position of the cotyledons in germination, the type of cotyledon, and the persistence of seed coat. For morphometry, all the parts that compose the seedling (root, hypocotyl, epicotyl, cotyledons and eophiles) were measured with a millimeter ruler, aiming to create an evaluation chart for seedling classification.

In the second stage of this study, seeds from five $A$. cearensis seed lots were used for evaluation of physiological quality. The moisture content of the seeds from each seed lot was determined from two replications of $4.5 \mathrm{~g}$ through 
the laboratory oven method at $105{ }^{\circ} \mathrm{C} / 24 \mathrm{~h}$ (Brasil, 2009) and results were obtained in percentage. To carry out the germination tests, two hundred seeds $(8 \times 25)$ from each lot were incubated in a B.O.D. germinator at $25^{\circ} \mathrm{C}$ and $12-\mathrm{h}$ photoperiod over thirty days, and the results were expressed in percentage of normal seedlings (strong and weak). For the field emergence test, two hundred $(4 \times 50)$ seeds from each seed lot were distributed in a seed bed in full sun, with subsoil as a substrate. On the thirtieth day after sowing, the percentages of emerged normal seedlings (strong and weak) were calculated (Brasil, 2013).

The germination speed index (GSI) was elaborated from daily counting of normal seedlings, and results were calculated according to the equation proposed by Maguire (1962). Regarding first germination count, seeds that gave rise to normal (strong and weak) seedlings were counted on the $11^{\text {th }}$ day after sowing, and results were expressed in percentage. For seedling length and dry matter, the seedlings were measured with a millimeter ruler, and results were expressed in $\mathrm{cm}$.seedling ${ }^{-1}$. The seedlings without the cotyledons were placed to dry in a forced air ventilation oven at $65^{\circ} \mathrm{C}$ for 48 hours.

For the tetrazolium test, the seeds were pre-hydrated in distilled water at $35^{\circ} \mathrm{C}$ for 24 hours in order to remove the integument and facilitate staining of the seeds. After that, four replications of 25 seeds were submersed in a $0.075 \%$ tetrazolium solution for three hours at $25{ }^{\circ} \mathrm{C}$ (Guedes et al., 2010). Then the seeds were classified in four classes, according to França-Neto et al. (1998): class 1 (viable - highly vigorous) - pink colored seeds; class 2 (viable vigorous) - seeds that have up to $40 \%$ of the cotyledons with strong carmine red or milky white color and the central cylinder with pink color; class 3 (viable - not vigorous) - more than $40 \%$ strong carmine red or milky white color in the cotyledons and around the central cylinder, which remains pink; and class 4 (not viable) - strong carmine red and milky white color in the central cylinder. For evaluation of viability, the percentage of seeds in classes 1, 2 and 3 was considered; whereas for vigor classification, the percentage in classes 1 and 2 was considered (Figure 1).

Seedlings were classified with the aid of an evaluation chart elaborated from the morphometry of the seedlings at the end of the germination test. The chart was organized on the following basis: adaptation of the methodology of Krzyzanowski and Nakagawa (1999), who considered the terminologies of strong and weak normal seedlings for seeds of cultivated plants; the criteria of normal seedlings (intact, with small defects, and with secondary infection) and abnormal seedlings described in the Rules for Seed Testing (Brasil, 2009); and the morphological description and morphometry of seedlings of the species.

From morphological and morphometric characterization of the seedlings, with the assistance of the chart, the seedlings were classified as strong normal seedlings, weak normal seedlings, and abnormal seedlings.

The morphometry of strong normal seedlings consisted of measuring each component part of the seedling (root, hypocotyl, epicotyl, eophiles, and cotyledons), and the evaluation chart was elaborated based on these data. The classification of strong normal seedlings was given to all seedlings that exhibited proportionality and intact essential structures according to the selection criteria of the evaluation chart, such as root length within the interval of 5-12.8 $\mathrm{cm}$, based on morphometry, and mean seedling length greater than or equal to nineteen $\mathrm{cm}$.

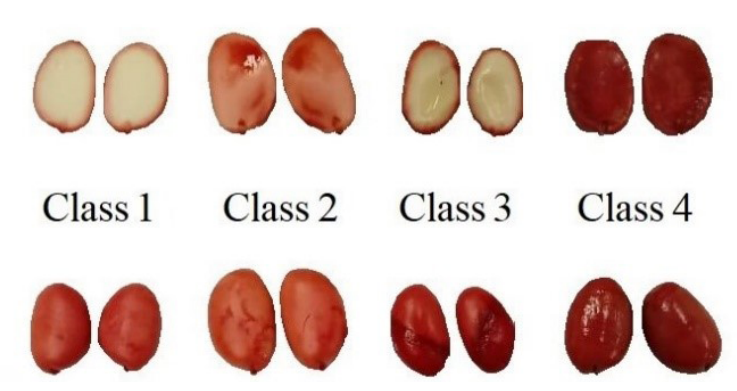

Class 1 - pink color; class 2 - up to $40 \%$ of the cotyledons with strong carmine red or milky white color and the center cylinder with pink color; class 3 - more than $40 \%$ strong carmine red or milky white color in the cotyledons and around the center cylinder, which remains pink; class 4-strong carmine red and milky white color in the center cylinder.

Figure 1. Classification of Amburana cearensis seeds for evaluation of viability and vigor through the tetrazolium test. 
Seedlings that had "small defects", such as necrosis spots on the roots and/or eophiles, mild twisting in hypocotyl, three cotyledons, root length less than five $\mathrm{cm}$, and total seedling length less than $19 \mathrm{~cm}$, were considered weak normal seedlings for the species under study.

In seedling morphology, abnormal seedlings were those that exhibited twisting in the root collar and root, spiral shape, necrosis and albinism.

Following the morphometric chart, seedlings classified as strong normal (intact plants) were counted for each lot, and data were expressed in percentage. After that, a complementary variable was joined with the strong normal seedling vigor test (SV), the length of strong normal seedlings (L-NS), in which the seedlings classified as strong normal seedlings were measured, and the result was expressed in $\mathrm{cm}^{\text {seedling }}{ }^{-1}$. The test of strong normal seedling vigor (SV) and length of strong normal seedlings (L-NS) were correlated with the other vigor tests (first germination count, GSI, emergence, tetrazolium, seedling length, and seedling dry matter).

Descriptive statistical analysis and frequency distribution were performed on the data regarding morphometry of the seedlings (all the parts that compose the seedling). For physiological characterization of the seeds of each seed lot, a completely randomized experimental design was used, with comparative tests (Tukey test at $1 \%$ probability) for parametric data and the Kruskal-Wallis test at 5\% probability for non-parametric data, applied to the mean values of the lots for each variable separately.

Due to the aim of adapting the methodology of the test of strong normal seedling vigor, correlation was considered only for the variables "strong normal seedlings" and "length of strong normal seedlings" with the "other vigor tests" using the Spearman and Pearson coefficients to check the levels of physiological quality of the seeds of each lot. For the correlation classification criteria, a "positive" or "negative" value of the $r$ coefficient will indicate a positive or negative association, respectively, between the variables. The greater the absolute value of the coefficient, the stronger the relationship between the variables - when the $r$ value was from 0.0 to 0.39 , the correlation was considered "weak"; from 0.4 to 0.69 , "moderate"; and from 0.7 to 1, "strong". The statistical software with Bioestat 5.0 was used in all the analyses (Ayres et al., 2007).

\section{RESULTS AND DISCUSSION}

Germination of $A$. cearensis seeds is in accordance with the semi-hypogeal phanerocotylar type, with primary root emergence on the fourth day and formation of normal seedlings on the ninth day after sowing (Figure 2). The root is cylindrical and initially of light gray color (10Y 8/8), later turning pale yellow (5Y 8/3); furthermore, it has a thin root cap of copper color (5YR 8/6) that is difficult to see with the naked eye (Figure 3A). This detail of the structure was not found by Cunha and Ferreira (2003); however, Loureiro et al. (2013) described it. The hypocotyl is short and of yellowish green color ( $5 \mathrm{GY} 7 / 4$ ), with lenticels across its entire length and rapid growth from the fifth to the ninth day after sowing (Figure 2).

The epicotyl is initially of light gray color (10Y 8/8), turning to yellowish green (5GY 7/4), with lenticels in the basal region and cataphylls in the intermediate region and/or near the eophiles. The cataphylls are specialized leaves and, in this case, they protect the lateral buds (Figure 3B). The cotyledons are opposite each other, isophyllous, and fleshy, with an oblong shape, and petiolate, with striation along the petiole (Figure 3C). They are initially of light gray color (10Y 8/8) and, after that, yellowish green (5GY 7/4), findings similar to those described by Loureiro et al. (2013).

The eophilesare imparipinnate, with five to seven leaflets with a short petiole (Figure 3D). They initially develop folded over, giving the impression of a pointed tip, which explains the difference from the morphological description made by Cunha and Ferreira (2003), because when the leaflets are fully open, they have an elliptical shape with a rounded base and tip and brochidodromous venation, yellowish green color (5GY 7/4), and short hairs spaced out on the abaxial surface (Figure $3 \mathrm{E}$ ). These observations show that there is divergence from the description made by Loureiro et al. (2013), who indicate leaves with a sharp tip and penniveined venation.

Seedling morphometry shows only the epicotyl near zero in asymmetry and kurtosis simultaneously (Table 1). 


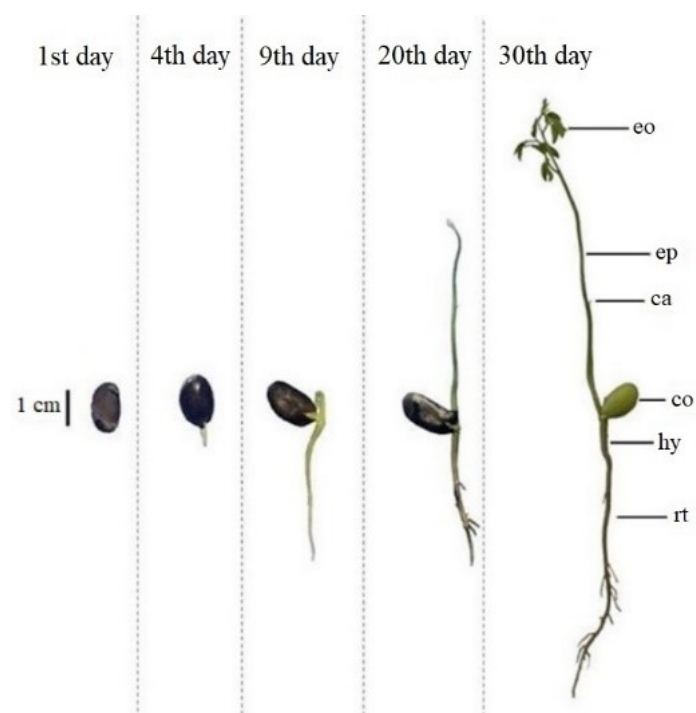

ca - cataphyll, co - cotyledons, eo - eophiles, ep - epicotyl, hy - hypocotyl, rt - root.

Figure 2. Germination process of a normal seedling of Amburana cearensis.

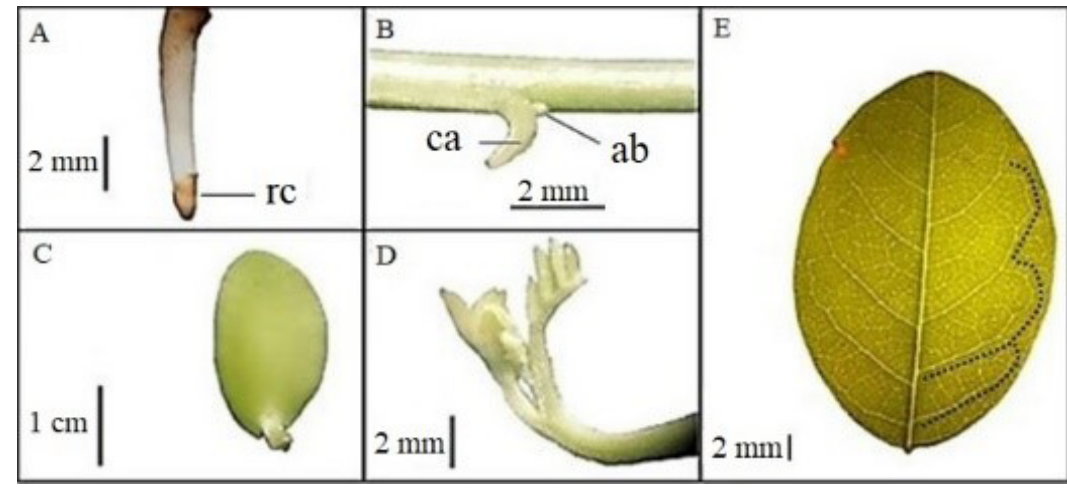

rc - root cap, ca - cataphyll, ab - axillary bud.

Figure 3. Primary root of Amburana cearensis with root cap (A), cataphyll (B), cotyledon (C), eophiles in development (D), and venation of leaflet (E).

Table 1. Descriptive statistics of morphometry of strong normal seedlings of Amburana cearensis.

\begin{tabular}{|c|c|c|c|c|c|c|c|c|}
\hline \multirow{2}{*}{ Variable } & Min. & Max. & Mean \pm Error & \multirow{2}{*}{ Variance } & \multirow{2}{*}{$\begin{array}{l}\text { Standard } \\
\text { Deviation }\end{array}$} & \multirow{2}{*}{ CV (\%) } & \multirow{2}{*}{ Asymmetry (G1) } & \multirow{2}{*}{ Kurtosis (G2) } \\
\hline & \multicolumn{3}{|c|}{$(\mathrm{cm})$} & & & & & \\
\hline Root & 5.0 & 12.8 & $7.78 \pm 0.31$ & 2.6 & 1.6164 & 21 & 1.0966 & 2.0741 \\
\hline Hypocotyl & 0.5 & 1.3 & $0.91 \pm 0.05$ & 0.1 & 0.2825 & 31 & 0.0453 & -1.467 \\
\hline Epicotyl & 6.4 & 14.0 & $10.30 \pm 0.35$ & 3.5 & 1.8826 & 18 & 0.0910 & -0.1767 \\
\hline Eophiles & 0.2 & 3.0 & $0.93 \pm 0.05$ & 0.2 & 0.4669 & 51 & 1.6307 & 4.1869 \\
\hline Cotyledon length & 1.4 & 2.9 & $2.11 \pm 0.06$ & 0.1 & 0.3202 & 15 & 0.0006 & 0.6583 \\
\hline Cotyledon width & 0.9 & 1.4 & $1.06 \pm 0.02$ & 0.0 & 0.1160 & 11 & 0.8427 & 1.1003 \\
\hline
\end{tabular}

Asymmetry in all the variables proved to be positive, and kurtosis is leptokurtic for the hypocotyl and epicotyl and platykurtic for roots, eophiles, and length and width of the cotyledons (Table 1). In statistical distribution, asymmetry determines the frequency of the distribution between values of 1 and -1 , in which deviation from the median and 
mode is observed in relation to the mean. Kurtosis measures the dispersion of the values, characterizing the degree of flatness of the frequency distribution (Acchile et al., 2017).

Roots were considered an important factor for differentiation between strong and weak normal seedlings, and their platykurtic distribution indicates low concentration of length values in the center (medial axis), with significant distribution below and above the mean, which allowed seedlings with root length from 5 to $12.8 \mathrm{~cm}$ to be classified as normal. The hypocotyl, however, was not significant for differentiation between strong and weak normal seedlings since its leptokurtic distribution indicates high concentration of values in the center and tail curve, i.e., low variance in length, making it impossible to classify seedlings by the criterion of hypocotyl length.

Strong normal seedlings of $A$. cearensis had proportional structures, with isophyllous cotyledons, in which pairs of them have the same length and width. Just as the cotyledons, the eophiles and the hypocotyl had a high coefficient of variation (51 and 31\%, respectively). This fact is probably due to the small number of structures evaluated, since, in the species studied, investment of energy expenditure apparent in primary growth of the root and later in the epicotyl is observed, and eophiles develop from half of the growth process of the seedling on.

The most recurrent weak normal seedlings of $A$. cearensis exhibited a slight twist in the collar, the region of transition of the hypocotyl and root; necrosis spots on the root, leading to its bifurcation; and development of axillary buds at the point of connection of the cotyledons to the stem when the epicotyl and/or cataphyll were damaged, leading to the formation of two new epicotyls identical to the epicotyl of seminal origin (Figure 4). This development of buds is not reported in the Rules for Seed Testing (Brasil, 2009) and, as this case was monitored after the germination test, it was found that individuals generated healthy and well-developed seedlings. Thus, these individuals can be classified as weak normal seedlings.

The most frequent abnormalities in the seedlings were those arising from necrosis and accentuated twisting of the collar and of the roots. Necrosis in only the eophiles did not affect epicotyl growth, and, in addition, there was growth of new eophiles from the bud protected by the cataphyll of the epicotyl of seminal origin; these were characterized as weak normal seedlings. Necrosis was also found on the epicotyls arising from the axillary buds, still in initial growth, characterizing them as abnormal seedlings.

The moisture contents of the seed lots were similar ( $\leq 0.8 \%$ among lots), (Table 2$)$. This nearness in moisture content is essential so that there is no interference in the result of the tests of physiological quality, recommending that the difference in these values be less than 2\% (Marcos-Filho, 2015; Javorski et al., 2018).

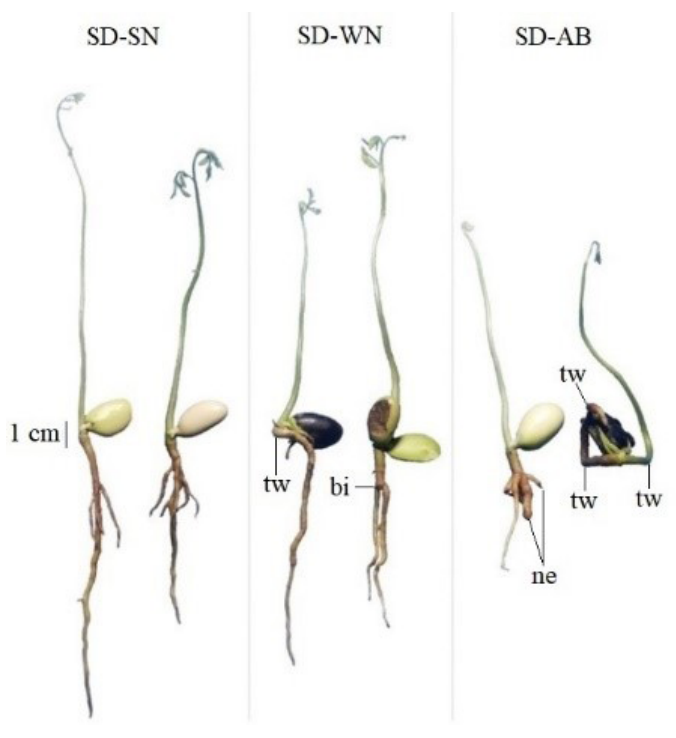

bi - bifurcation, ne - necrosis, tw - twisting.

Figure 4. Classification of Amburana cearensis seedlings into strong normal (SD-SN), weak normal (SD-WN), and abnormal (SD-AB) categories. 
Table 2. Moisture content (MC), germination (G), emergence (E), seed viability and vigor by tetrazolium (T-VB and T-VG), first germination count (FGC), strong normal seedling vigor (SV), germination speed index (GSI), seedling length (SD-L), length of strong normal seedlings (L-NS), and seedling dry matter (SD-DM) of Amburana cearensis.

\begin{tabular}{|c|c|c|c|c|c|}
\hline \multirow{2}{*}{ Variable } & \multicolumn{5}{|c|}{ Seed lot } \\
\hline & 1 & 2 & 3 & 4 & 5 \\
\hline MC (\%) & 7.2 & 6.7 & 6.9 & 6.4 & 6.8 \\
\hline $\mathrm{G}^{*}(\%)$ & $82 \pm 1.7 \mathrm{ab}$ & $70 \pm 3.8 b$ & $83 \pm 5.4 \mathrm{ab}$ & $87 \pm 2.6 a$ & $79 \pm 2.9 a b$ \\
\hline$E(\%)$ & $79 \pm 2.2 \mathrm{a}$ & $78 \pm 8.8 a$ & $83 \pm 4.4 a$ & $81 \pm 3.3 \mathrm{a}$ & $72 \pm 5.1 \mathrm{a}$ \\
\hline $\mathrm{T}^{-V B^{*}}$ & $86 \pm 2.6 a$ & $93 \pm 3.4 a$ & $92 \pm 3.2 \mathrm{a}$ & $98 \pm 1.2 \mathrm{a}$ & $92 \pm 3.2 \mathrm{a}$ \\
\hline $\mathrm{T}-\mathrm{VG}^{* *}$ & $69 \pm 3.8 b$ & $78 \pm 3.8 \mathrm{ab}$ & $69 \pm 3.4 b$ & $92 \pm 3.3 \mathrm{a}$ & $69 \pm 5 b$ \\
\hline $\mathrm{FGC}^{*}(\%)$ & $4 \pm 1.6 \mathrm{ab}$ & $10 \pm 2.6 a$ & $1 \pm 0.5 b$ & $4 \pm 1.2 \mathrm{ab}$ & $3 \pm 1.5 \mathrm{ab}$ \\
\hline $\mathrm{SV}^{* *}(\%)$ & $45 \pm 5.7 b$ & $51 \pm 4.6 \mathrm{ab}$ & $29 \pm 3.0 b$ & $65 \pm 3.5 \mathrm{a}$ & $51 \pm 5.8 \mathrm{ab}$ \\
\hline $\mathrm{GSI}^{* *}$ & $1.06 \pm 0.0 \mathrm{ab}$ & $1.22 \pm 0.1 \mathrm{a}$ & $0.90 \pm 0.1 b$ & $1.18 \pm 0.0 \mathrm{a}$ & $1.15 \pm 0.0 \mathrm{a}$ \\
\hline SD-L ${ }^{* *}\left(\mathrm{~cm} \cdot\right.$ seedling $\left.^{-1}\right)$ & $15.9 \pm 0.6 \mathrm{ab}$ & $15.6 \pm 1.0 \mathrm{ab}$ & $14.7 \pm 1.1 \mathrm{~b}$ & $19.9 \pm 0.8 \mathrm{a}$ & $16.4 \pm 0.9 \mathrm{ab}$ \\
\hline L-NS $^{* *}\left(\mathrm{~cm}\right.$. seedling $^{-1}$ ) & $9.4 \pm 1.6 b$ & $11.9 \pm 1.2 \mathrm{ab}$ & $7.0 \pm 1.2 b$ & $15.5 \pm 1.0 \mathrm{a}$ & $11.1 \pm 1.4 \mathrm{ab}$ \\
\hline $\mathrm{SD} \mathrm{DM}^{* *}\left(\mathrm{mg} \cdot\right.$ seedling $\left.^{-1}\right)$ & $72.9 \pm 2.0 \mathrm{~b}$ & $73.6 \pm 3.4 \mathrm{ab}$ & $72.5 \pm 4.6 b$ & $88.6 \pm 4.6 \mathrm{a}$ & $78.4 \pm 1.4 \mathrm{ab}$ \\
\hline
\end{tabular}

*Mean values followed by the same letters in the row do not differ statistically from each other by the Kruskal-Wallis Test at $5 \%$ probability.

${ }^{* *}$ Mean values followed by the same letters in the row do not differ statistically from each other by the Tukey Test at $1 \%$ probability.

Germination showed a statistical difference only between lots 2 and 4, in which lot 2 expressed low viability in relation to lot 4 , without statistical differences being observed (at $5 \%$ probability) of these lots compared to lots 1 , 3 and 5 (Table 2). In the germination test, hard and dormant seeds were not observed, and the ungerminated seeds were dead and/or in an advanced state of contamination by microorganisms. Seedling emergence did not show a statistical difference at $5 \%$ probability among the seed lots, while first germination count and the germination speed index (GSI) were statistically similar to the results of lot 4, in spite of the inferior result of germination for the seeds of lot 2 (Table 2).

The GSI of the $A$. cearensis seeds ranged from 0.9 to 1.22 , indicating that the values near zero emphasize the need for a minimum of thirty days for final evaluation of germination. In spite of that, the GSI was able to differentiate physiological quality, showing that the seeds of lots 1, 2, 4 and 5 have higher speeds of germination than those of lot 3 (Table 2).

In first germination count, difference was found only between lots 2 and 3 ( $10 \%$ and 1\%, respectively). The low germination percentage in the first count is characteristic of the species, which has a slow and uneven germination process, as observed in the results of germination speed (Table 2). The first count and GSI tests are interdependent because the greater percentage of seedlings in the first evaluation means seed germination speed was rapid in a determined lot (Nakagawa, 1994). This is confirmed in the results of this study, in which vigor levels obtained in the first germination count and in GSI of seeds from the different lots were similar (Table 2).

The length of seedlings coming from seeds of lot 4 was significantly greater than that of seedlings coming from lot 3. It was found that the length of strong normal seedlings and dry matter had similar rankings, with the seeds from lot 4 resulting in greater length and dry matter $\left(15.5 \mathrm{~cm}\right.$. seedling $^{-1}$ and $88.6 \mathrm{mg}^{\text {seedling }}{ }^{-1}$, respectively) of seedlings compared to those of lots 1 and 3 ( 9.4 and $7 \mathrm{~cm}$.seedling ${ }^{-1} ; 72.9$ and $72.5 \mathrm{mg}$.seedling ${ }^{-1}$ ) (Table 2). In the seedling length and dry matter tests, it should be considered that seeds from the most vigorous lots give rise to seedlings of greater length and dry matter, due to greater capacity for transformation of plant tissues and translocation of reserves (Amaro et al., 2015) from the cotyledons or from the endosperm for growth of the embryonic axis.

Viability by the tetrazolium test, which considered all the seeds from classes 1, 2 and 3, was also not effective for evaluating quality differences among the seed lots (Table 2). Nevertheless, in evaluation of vigor by the tetrazolium 
test, in which the total percentage of seeds of only classes 1 and 2 was considered, physiological ranking was found in three vigor levels: lot 4 was considered to be of high vigor because it was superior to lots 1, 3 and 5 (lots of low vigor), but did not differ from the seeds of lot 2, whose quality was considered to be intermediate (Table 2).

In the seedling vigor test, the seeds of lot 4 gave rise to $65 \%$ strong normal seedlings, which was superior to the seeds of lots 1 (45\%) and 3 (29\%), which did not differ from each other and were considered to be of low vigor. In contrast, the seeds from lot 2 and 5 (both with 51\% strong normal seedlings) did not differ from each other and were classified as medium vigor (Table 2).

Tests based on seedling performance have been increasingly studied for evaluation of seed physiological quality. These tests are not simply complementary to the germination test, but protagonistic, in light of their speed and effectiveness, especially the seedling length test (Sena et al., 2015). The test of primary root length of $A$. cearensis seedlings was recommended over other vigor tests for evaluation of physiological quality due to its sensitivity for classification in vigor levels (Guedes et al., 2015).

Correlations among the physiological vigor tests (first germination count, tetrazolium, seedling length, and seedling dry matter) and the strong normal seedling vigor test were significant only for seedling length, length of strong normal seedlings, and GSI. The two variables for length had strong positive correlation, in which strong normal seedling length had greater correlation ( $r=0.9275$ ) (Table 3$)$. Therefore, the variables analyzed are proportional.

Length of strong normal seedlings had correlation with the other variables only for total seedling length, vigor of strong normal seedlings, and GSI (Table 3). The fact that the correlation is positive implies that the greater the length of the strong normal seedlings, the greater seedling length, strong normal seedling vigor, and GSI will be. The Spearman and Pearson correlation coefficient ranges from -1 to 1 ; the nearer 1 or -1 , the stronger the correlation, and proximity to zero shows that correlation is weak.

Correlation for purposes of evaluation of the efficacy of vigor tests can lead to incomplete information since its significance indicates similarity of variation between two variables, but not necessarily their precision in estimation of

Table 3. Correlation between strong normal seedling vigor of Amburana cearensis (SV) and length of strong normal seedlings (L-NS) and the other variables analyzed.

\begin{tabular}{|c|c|c|c|}
\hline Correlation & Coefficient $(r)$ & $\mathrm{P}$ & Correlation \\
\hline SV (\%) X L-NS (cm.seedling ${ }^{-1}$ ) & $0.9275^{*}$ & $<0.0001$ & Strongly positive \\
\hline L-NS (cm.seedling ${ }^{-1}$ ) X SD-L (cm.seedling ${ }^{-1}$ ) & $0.7918^{*}$ & $<0.0001$ & Strongly positive \\
\hline SV (\%) X SD-L (cm.seedling $\left.{ }^{-1}\right)$ & $0.7857^{*}$ & $<0.0001$ & Strongly positive \\
\hline GSI X L-NS (cm.seedling ${ }^{-1}$ ) & $0.5816^{*}$ & $<0.0001$ & Moderately Positive \\
\hline GSI X SV (\%) & $0.5646^{*}$ & $<0.0001$ & Moderately Positive \\
\hline SV (\%) X FGC & $0.1475^{*}$ & 0.3638 & $\mathrm{Ns}$ \\
\hline SV (\%) X SD-DM (mg.seedling-1) & $0.3349^{*}$ & 0.0346 & Ns \\
\hline SV $(\%) \times E(\%)$ & $0.1805^{* *}$ & 0.4463 & Ns \\
\hline SV (\%) X T-VG (\%) & $-0.052^{* *}$ & 0.8276 & Ns \\
\hline L-NS (cm.seedling ${ }^{-1}$ ) X FGC (\%) & $0.1561^{*}$ & 0.3362 & Ns \\
\hline L-NS (cm.seedling ${ }^{-1}$ ) X SD-DM (mg.seedling ${ }^{-1}$ ) & $0.2555^{*}$ & 0.1114 & Ns \\
\hline L-NS (cm.seedling ${ }^{-1}$ ) X E (\%) & $-0.1673^{*}$ & 0.302 & Ns \\
\hline L-NS (cm.seedling ${ }^{-1}$ ) X T-VG (\%) & $-0.2705^{*}$ & 0.0913 & Ns \\
\hline
\end{tabular}

FGC: first germination count; GSI: germination speed index; SD-L: seedling length; SD-DM: seedling dry matter; E: emergence; T-VG: tetrazolium test in vigor classification.

*Spearman coefficient.

***earson coefficient.

Ns: not significant. 
the physiological quality of seeds themselves. Therefore, correlation should be applied as a complementary statistical model to understand the variations among the tests evaluated in a determined study (Sena et al., 2015).

In the present study, correlation was not carried out between the viability (germination) test and the vigor tests, because the intent was to check if the physiological ranking of the "strong normal seedling vigor" (SV) and "length of strong normal seedling" (L-NS) tests led to similarities with the vigor levels obtained in the other vigor tests. In addition, comparing viability tests (such as the germination test) in which the germination percentage of seeds from the different lots was similar is not justifiable (Table 2).

The effectiveness of the strong normal seedling vigor test was confirmed because it led to the same physiological ranking as the length of strong normal seedling and seedling dry matter tests, classifying the lots in three vigor levels (high, medium and low). Similar results were also obtained by the tetrazolium seed vigor test. Thus, lot 4 was established as more vigorous than lots 1 and 3 , whereas lots 2 and 5 were considered to be of intermediate physiological quality.

\section{CONCLUSIONS}

From morphological classification of seedlings into strong normal, weak, and abnormal seedlings, it is possible to adapt the normal intact (strong) seedling vigor test of $A$. cearensis.

The vigor test based on identification and quantification of strong normal seedlings, evaluation of length of strong normal seedlings, and application of the seed vigor test through tetrazolium were effective for classification of vigor of A. cearensis seed lots.

\section{ACKNOWLEDGMENTS}

The present study was carried out with support from the Coordenação de Aperfeiçoamento de Pessoal de Nível Superior (CAPES), Funding Code 001. Our thanks also for support from the Agrarian Sciences Specialized Academic Unit of the Universidade Federal do Rio Grande do Norte, Macaíba, RN, where the study was conducted.

\section{REFERENCES}

ACCHILE, S.; COSTA, R.N.; SILVA, L.K.S.; SANTOS, J.C.C.; SILVA, D.M.R.; SILVA, J.V. Biometria de frutos e sementes e determinação da curva de absorção de água de sementes de Sesbania virgata (Cav.). Pers. Scientific Electronic Archives, v.10, n.5, p.26-34, 2017. http://www.seasinop.com.br/revista/index.php?journal=SEA\&page=article\&op=view\&path\%5B\%5D=480\&path\%5B\%5D=pdf

ALMEIDA, J.P.N.; LESSA, B.F.T.; PINHEIRO, C.L.; GOMES, F.M.; MEDEIROS-FILHO, S.; SILVA, C.C. Germination and development of Amburana cearensis seedlings as influenced by seed weight, light and temperature. Acta Scientiarum, v.39, n.4, p.525-533, 2017. http://www.scielo.br/pdf/asagr/v39n4/1807-8621-asagr-39-04-00525.pdf

AMARO, H.T.R.; DAVID, A.M.S.S.; ASSIS, M.O.; RODRIGUES, B.R.A.; CANGUSSÚ, L.V.S.; OLIVEIRA, M.B. Testes de vigor para avaliação da qualidade fisiológica de sementes de feijoeiro. Revista de Ciências Agrárias, v.38, n.3, p.383-389, 2015. http://www.scielo.mec. pt/scielo.php?script=sci_arttext\&pid=S0871-018X2015000300013

AYRES, M.; AYRES-JUNIOR, M.; AYRES, D.L.; SANTOS, A.A.S. Bioestat 5.0 aplicações estatísticas nas áreas das ciências biológicas e médicas. Belém: IDSM, 2007.364p.

BRASIL. Ministério da Agricultura, Pecuária e Abastecimento. Instruções para análises de sementes de espécies florestais. Ministério da Agricultura, Pecuária e Abastecimento. Secretaria de Defesa Agropecuária. Brasília: MAPA/ACS, 2013. 98p. http://www. agricultura.gov.br/assuntos/laboratorios/arquivos-publicacoeslaboratorio/florestal_documento_pdf-ilovepdf-compressed.pdf

BRASIL. Ministério da Agricultura, Pecuária e Abastecimento. Regras para análise de sementes. Ministério da Agricultura, Pecuária e Abastecimento. Secretaria de Defesa Agropecuária. Brasília: MAPA/ACS, 2009. 395p. http://www.agricultura.gov.br/assuntos/ insumos-agropecuarios/arquivos-publicacoes-insumos/2946_regras_analise_sementes.pdf

CAMPOS, V.C.A.; BRITO, A.L.; BUTIERREZ, I.E.M.; SANTANA, J.R.F.; SOUZA, A.V.V. Micropropagação de umburana de cheiro. Ciência Rural, v.43, n.4, p.639-644, 2013. http://www.scielo.br/pdf/cr/v43n4/a10713cr6875.pdf 
CUNHA, M.C.L.; FERREIRA, R.A. Aspectos morfológicos da semente e do desenvolvimento da planta jovem de Amburana cearensis (Arr. Cam.) A.C. Smith - cumaru - Leguminosae Papilionoideae. Revista Brasileira de Sementes, v.25, n.2, p.89-96, 2003. http:// www.scielo.br/pdf/\%0D/rbs/v25n2/19654.pdf

FRANÇA-NETO, J.B.; KRZYZANOWSKI, F.C.; COSTA, N.P. O teste de tetrazólio em sementes de soja. Londrina: EMBRAPA-CNPSo, 1998. 72p.

GUEDES, R.S.; ALVES, E.U.; GONÇALVES, E.P.; VIANA, J.S.; SILVA, K.B.; GOMES, M.S.S. Metodologia para teste de tetrazólio em sementes de Amburana cearensis (Allemão) A.C. Smith. Revista Brasileira de Plantas Medicinais, v.12, n.1, p.120-126, 2010. http:// www.scielo.br/pdf/rbpm/v12n1/v12n1a17.pdf

GUEDES, R.S.; ALVES, E.U.; SANTOS-MOURA, S.S.; GALINDO, E.A. Teste de comprimento de plântula na avaliação da qualidade fisiológica de sementes de Amburana cearensis (Allemão) A.C. Smith. Semina: Ciências Agrárias, v.36, n.4, p.2373-2382, 2015. https://www.researchgate.net/publication/282423364_Teste_de_comprimento_de_plantula_na_avaliacao_da_qualidade_ fisiologica_de_sementes_de_Amburana_cearensis_Allemao_AC_Smith

JAVORSKI, M.; CASTAN, D.O.C.; SILVA, S.S.; GOMES-JUNIOR, F.G.; CICERO, S.M. Image analysis to evaluate the physiological potential and morphology of pearl millet seeds. Journal of Seed Science, v.40, n.2, p.127-134, 2018. http://www.scielo.br/pdf/jss/ v40n2/2317-1545-jss-40-02-127.pdf

KRZYZANOWSKI, F.C.; NAKAGAWA, J. Teste de vigor baseados no desempenho das plântulas. In: KRZYZANOSWKI, F.C.; VIEIRA, R.D.; FRANÇA-NETO. J.B. Vigor de sementes: conceitos e testes. Londrina: ABRATES, 1999. $218 p$.

LOPES, A.A.; MAGALHÃES, T.R.; UCHÔA, D.E.A.; SILVEIRA, E.R.; AZZOLINI, A.E.C.S.; KABEYA, L.M.; LUCISANO-VALIM, Y.M.; VASCONCELOS, S.M.M.; VIANA, G.S.B.; LEAL, L.K.A.M. Afrormosin, an isoflavonoid from Amburana cearensis A. C. Smith, modulates the inflammatory response of stimulated human neutrophils. Basic \& Clinical Pharmacology \& Toxicology, v.113, n.6, p.363-369, 2013. https://onlinelibrary.wiley.com/doi/full/10.1111/bcpt.12106

LOUREIRO, M.B.; TELES, C.A.S.; VIRGENS, I.O.; ARAÚJO, B.R.N.; FRENANDEZ, L.G.; CASTRO, R.D. Aspectos morfoanatômicos e fisiológicos de sementes e plântulas de Amburana cearensis (Fr. All.) A.C. Smith (Leguminosae - Papilionoideae). Revista Árvore, v.37, n.4, p.679-689, 2013. http://www.scielo.br/pdf/rarv/v37n4/11.pdf

MAGUIRE, J.D. Speeds of germination-aid selection and evaluation for seedling emergence and vigor. Crop Science, v.2, p.176-177, 1962.

MARCOS-FILHO, J. Seed vigor testing: an overview of the past, present and future perspective. Scientia Agricola, v.72, n.4, p.363374, 2015. http://www.scielo.br/pdf/sa/v72n4/0103-9016-sa-72-4-0363.pdf

MIQUEL, S. Morphologie fonctionelle de plantules d'espèces forestières du Gabon. Bulletin du Muséum d'Histoire Naturelle, v.9, n.4, p.101-121, 1987.

MUNSELL COLOR (FIRM). Munsell Color Charts for Plant Tissues. 2. ed. Baltimore, 1963.

NAKAGAWA, J. Testes de vigor baseados no crescimento de plântulas. In: VIEIRA, R.D.; CARVALHO, N.M. Testes de vigor em sementes. Jaboticabal: FUNEP, 1994. 164p.

SÁ, M.B.; RALPH, M.T.; NASCIMENTO, D.C.O.; RAMOS, C.S.; BARBOSA, I.M.S.; SÁ, F.B.; LIMA-FILHO, J.V. Phytochemistry and preliminary assessment of the antibacterial activity of chloroform extract of Amburana cearensis (Allemão) A.C. Sm. against Klebsiella pneumoniae carbapenemase-producing strains. Evidence-Based Complementary and Alternative Medicine, v.2014, 2014. http:// downloads.hindawi.com/journals/ecam/2014/786586.pdf

OLIVEIRA, A.C.S.; MARTINS, G.N.; SILVA, R.F.; VIEIRA, H.D. Testes de vigor em sementes baseados no desempenho de plântulas. Revista Cientifica Internacional, v.1, n.4, p.1-21, 2009. http://www.interscienceplace.org/isp/index.php/isp/article/view/35/34

SENA, D.V.A.; ALVES, E.U.; MEDEIROS, D.S. Vigor de sementes de milho cv. "Sertanejo" por testes baseados no desempenho de plântulas. Ciência Rural, v.45, n.11, p.1910-1916, 2015. http://www.scielo.br/pdf/cr/v45n11/1678-4596-cr-45-11-01910.pdf

SOUZA, T.S.; SOUZA, T. M.; PANOBIANCO, M. Morphological characterization of fruit, seed and seedling, and seed germination test of Campomanesia guazumifolia. Journal of Seed Science, v.40, n.1, p.75-81, 2018. http://www.scielo.br/pdf/jss/v40n1/2317-1537jss-40-01-75.pdf 